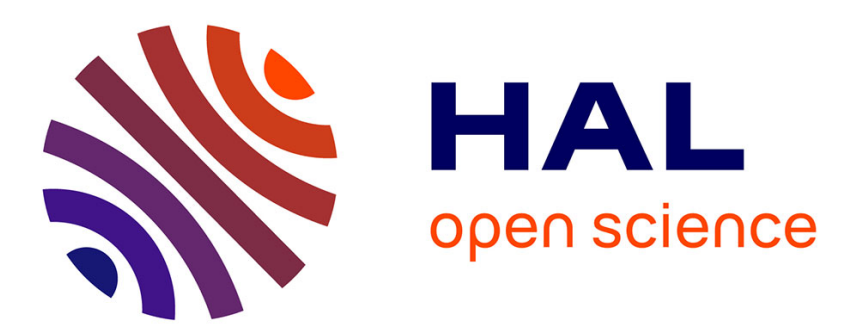

\title{
Comparison of childhood adversities and their possible consequences in Poland and Germany
}

\author{
Jochen Hardt, Malgorzata Dragan, Sonja Schultz, Katarzyna Schier
}

\section{To cite this version:}

Jochen Hardt, Malgorzata Dragan, Sonja Schultz, Katarzyna Schier. Comparison of childhood adversities and their possible consequences in Poland and Germany. Journal of Public Health, 2010, 19 (S1), pp.29-37. 10.1007/s10389-010-0375-1 . hal-00615350

\section{HAL Id: hal-00615350 \\ https://hal.science/hal-00615350}

Submitted on 19 Aug 2011

HAL is a multi-disciplinary open access archive for the deposit and dissemination of scientific research documents, whether they are published or not. The documents may come from teaching and research institutions in France or abroad, or from public or private research centers.
L'archive ouverte pluridisciplinaire HAL, est destinée au dépôt et à la diffusion de documents scientifiques de niveau recherche, publiés ou non, émanant des établissements d'enseignement et de recherche français ou étrangers, des laboratoires publics ou privés. 
The comparison of childhood adversities and their possible consequences in

Poland and Germany

\title{
Running head: childhood adversities in Poland and Germany
}

\author{
Jochen Hardt ${ }^{1}$ \\ Malgorzata Dragan ${ }^{2}$ \\ Sonja Schultz ${ }^{1}$ \\ Katarzyna Schier ${ }^{2}$
}

${ }^{1}$ Institute for Medical Psychology and Medical Sociology, University Medical Center,
Johannes Gutenberg-University Mainz
${ }^{2}$ Faculty of Psychology, University of Warsaw

Corresponding author:

Dr. J. Hardt

Institute for Medical Psychology and Medical Sociology

Clinic for Psychosomatic Medicine and Psychotherapy

Johannes Gutenberg-University Mainz

55128 Mainz

Email: hardt@mail.uni-mainz.de

Phone: 00496131 3925290, Fax: 004961313922750

Word Count:

Abstract: 164

Text (w/o. List of references): 3438, 4 tables 
The comparison of childhood adversities and their possible consequences in Poland and Germany

Running head: childhood adversities in Poland and Germany

Word Count:

Abstract: 181

Text (w/o. List of references): 3800, 5 tables 


\section{Abstract}

Aim: How children grow up differs from country to country. The aim of the present investigation was to compare childhood experiences, family characteristics, and psychological features during the post World War II period in Poland and Germany. Subject and Methods: A questionnaire regarding various childhood experiences and family circumstances was administered to two samples, one each in Poland and Germany ( $\mathrm{n}=500$ each) via Internet. Comparisons between Poland and Germany were performed by use of ANOVA and $\mathrm{X}^{2}$-tests, logistic regressions were performed to compare the effects of risk factors.

Results: Probands from Poland described almost all aspects of their lives, their families, and their childhoods as having been better than did probands from Germany. Risk factor for suicide attempts were childhood physical abuse, and for alcohol abuse gender and childhood sexual abuse in both countries. Conclusion: There is some evidence for idealisation of the past in Poland, which might be due to the fact that almost $90 \%$ of the Poles were Christians. Germans seem to be more realistic in their views of the past but possibly deny their personal weaknesses.

Key words: childhood adversities, family atmosphere, psychometric assessment, international survey 


\section{INTRODUCTION}

Adverse childhood experiences have been reported from countries all over the world. Worldwide, we face rates of childhood sexual abuse before the age of 14 of about $2 \%$ for boys and $5 \%$ for girls (Andrews et al. 2002). The overall percentages for child maltreatment range from about 10\% (Finkelhor et al. 2009) to about 50\% (Euser et al. 2010); such large variations are due to different definitions of maltreatment. Physical, sexual abuse and neglect are most apparent (Dong et al. 2004), but there are additional adverse childhood experiences, e.g. parental discord or parental mental disorders such as depression and alcohol abuse, which may be associated with long-term sequelae (Hardt 2004; Hardt et al. 2007). In addition, social, economic, and cultural circumstances have an impact on how children are perceived by parents, on child-rearing practices, and on aspects of the parent-child relationship (Schier 2009). Children who grow up in adverse social circumstances have a greater risk for unhealthy exposures such as environmental tobacco smoke and fewer opportunities for physical activity (Bolte et al.). Furthermore, children with low levels of education have a greater risk for mental health problems (Havas et al. 2009) and unhealthy behaviours such as smoking and risky alcohol use. (Drieskens et al. 2009). Likewise, childhood experiences of maltreatment are associated with psychiatric disorders and health-related risk behaviours (Felitti and Anda 2009) as well as marital difficulties in adult life (DiLillo et al. 2009).

Poland and Germany have had different histories over the past 50 years. The period of poverty after World War II ended relatively quickly in Germany but was prolonged in Poland during the communist regime until 1989. Even after the end of that regime, Poland could only slowly and partly catch up to Western standards. Unemployment, basically not existent during the communistic area, reached rates of about $20 \%$ in 2002, and was associated with increased death rates particularly for suicide and as consequence of alcohol abuse (relative risks 3: Zagozdzon et al. 2009). Still in 2009, the average income per month in Poland was $€ 730$ (GUS 2009), whereas in Germany it was $€ 2500$ (Statistisches Bundesamt 2009b).

The aim of the present paper was to systematically compare reports from subjects who grew up in Poland with those who grew up in Germany during this period. In addition, childhood sexual and physical abuse as risk factors for suicide 
attempts and alcohol abuse were compared in both countries. Due to the communist era in Poland, we divided the sample at the age of 40 . Because the survey was performed in 2008, the older individuals in the Polish sample grew up mainly under the communist regime; the younger persons experienced mainly capitalist social and economic rules. Germany underwent a union between its communist eastern part and capitalist western part in 1989. There also were economic differences, i.e. in Germany the communist East was (and still is) poorer than the West, but the differences were smaller in comparison to the change of systems that people experienced in Poland.

\section{METHOD}

\subsection{SAMPLE}

Subjects were asked via Internet to fill out a survey containing about 280 items. The questions about childhood (Hardt et al. 2003) constituted one of various sections in the item set and were located in the middle of the survey. The items were translated from German into Polish by a native Polish speaker (KS) and backtranslated into German by a native German speaker who never saw the original German ones. The two German versions were compared by $\mathrm{JH}$, and discrepancies were discussed thoroughly by $\mathrm{MD}$ and $\mathrm{JH}$. Data collection was performed by a professional marketing institute, where participants were registered to fill out online questionnaires ( $\mathrm{http}: / / w w w . l i n e q u e s t . d e)$. In most cases they do marketing research. The participants were informed via email that the present questionnaire served research purposes and that we were interested in various circumstances of life. Data collection took about one week in each country. During this time, information in Polish and German was put onto the homepage of the University of Mainz in order to enable the subjects to verify the scientific background of the study. Participants received compensation of about $€ 4,30$ for filling out the questionnaire. The ethics committees of the Universities of Duesseldorf and Mainz approved the project (project nos. 3063 and 6281, respectively). There was some rather positive feedback from individual subjects, who said that this questionnaire was interesting to fill out. 


\subsection{VARIABLE DESCRIPTION}

Questions about demographics assessed factors such as age and sex, partner in life, and job status. Childhood experiences comprised 17 questions, e.g. number of siblings, parental physical and mental health, parental pain and alcohol abuse, and parental discord. Four questions concerned own physical abuse: (1) regular harsh punishment, (2) having been beaten so that bruises occurred, (3) parents' threatening behaviour, and (4) violence between parents. Sexual abuse was assessed by posing the following three questions: (1) Did you have any unwanted sexual experience with someone at least five years older than you before you reached the age of 15? (2) If so, would you consider it as abuse? and (3) Who was the perpetrator? One's own alcohol abuse was assessed by the CAGE questionnaire (Ewing 1984). We did not include questions about drugs other than alcohol because the rates were very low in Poland and Germany. Lifetime suicidality was assessed by a question with five possible answers: (1) Suicide attempt, (2) Plan, (3) Ideation, (4) No suicidality, and (5) Don't know/Refuse to answer.

\subsection{STATISTICAL ANALYSIS}

Comparisons between Poland and Germany as well as between the young and old age groups were performed by use of ANOVA for continuous variables and $X^{2}$-tests for categorical variables. Logistic regression analyses were performed to predict suicide attempts and possible alcohol abuse by childhood sexual and physical abuse. Both responses were dichotomised: i.e. suicide attempts vs no suicide attempts, possible alcohol abuse "yes" when the sum of the four cage questions were two or higher, and "no" when it was zero ore one. Beside main effects, interaction terms for abuse and country were included into the analysis. The alpha level for all statistical tests was set to .01 (two-tailed). Hence, an effect size for a simple cross-national mean comparison (Cohen 1988) of $d<.15$ was nonsignificant in the present sample. This alpha level was set to balance statistical and clinical significance. Trends were not interpreted. There were no missing items in 
the Internet surveys; the programme prompted the respondent for an answer when an item was left open. Calculations were performed by use of STATA 9.2 (StataCorp 2004) and SPSS V17 (SPSS inc. 2009).

\section{RESULTS}

We present the results in four groups: (1) demographics and general background, (2) family problems (the image of the mother, the father, and their relationship), (3) forms of abuse, and (4) alcohol consumption and suicidal ideation).

3. 1. Demographics and general background

(Please insert Table 1 about here)

As seen in Table 1, there were slightly more females (about 55\%) than males in both samples. The average age was about 39 years. Regarding current partner in life, most respondents from both countries were married or had been living with a partner for more than six months. In both countries, the older groups were more often married than the younger groups $\left(X^{2}=131, p<.001\right)$. Regarding job status, Polish respondents designated themselves mostly as on level II of the Registrar General's Classification System (Goldthorpe and Hope 1974); in contrast, Germans settled mainly on level IIIa $\left(X^{2}=204, p<.001\right)$. There were neither age nor sex differences.

Concerning religiousness, there were prominent differences between the two countries $\left(X^{2}=314, p<.001\right)$. In Poland, almost $90 \%$ of the participants were Christians, whereas in Germany only about $50 \%$ were Christians. In contrast, the percentage of non-church members was about $50 \%$ in Germany, compared with only $10 \%$ in Poland. In addition, there was an age effect: older people tended to be more religious.

(Please insert Table 2 about here) 
Polish subjects significantly more often reported that they believed they had been a planned child $(80 \%)$, compared with Germans $\left(50 \% ; X^{2}=124, p<.001\right)$. No age effect was seen in either country. The rooms per person in the household differed significantly between the countries; in Germany there was more space $\left(X^{2}=\right.$ $143, p<.001)$. Furthermore, there was an age effect; younger probands reported having more space.

A feeling of having felt secure at home was reported more often in Poland than in Germany ( $\left.X^{2}=51.0, p<.001\right)$; no age effect was observed. Absence of a parent for more than six months was reported by $80 \%$ of the Poles, compared with only $23 \%$ of the Germans $\left(X^{2}=319, p<.001\right)$, with no age effect. German and Polish subjects did not differ significantly in having grandparents who cared for them $\left(X^{2}=7.52 ; p=.057\right)$. The number of siblings was smaller for the younger groups in both countries $\left(X^{2}=23.3, p<.001\right)$; in Germany the difference was larger than in Poland. Having been successful at school was more often reported by Poles than by Germans $\left(X^{2}=63.6, p<.001\right)$, whereas having been a member of a youth group was more often reported by Germans $\left(X^{2}=22.7, p<.001\right)$.

\section{2. Description of the family}

Chronic maternal illness or disability did not differ between the countries but showed a strong age effect (Table 2). In the younger groups about $6 \%$ of mothers were said to have been chronically ill or handicapped; in the older groups the percentage was about $12 \%\left(X^{2}=11.6, p=.009\right)$. Regarding the question of whether their fathers were chronically ill or handicapped, German and Polish subjects again did not differ in their answers $\left(X^{2}=5.03, p=.170\right)$; however, there was no age effect. Maternal chronic pain was reported more often in Poland than in Germany, and the rates in the older groups were about twice as high as in the younger groups $\left(X^{2}=23, p<.001\right)$. Regarding paternal chronic pain, Germans reported higher values than Poles, and again the older groups reported more pain $\left(X^{2}=11.5, p<\right.$ .009). In Germany, $20 \%$ of the younger respondents and $26.8 \%$ of the older ones reported maternal mental illness, whereas in Poland only $11 \%$ of the younger respondents and $4 \%$ of the older ones did so $\left(X^{2}=57, p<.001\right)$. Paternal mental illness in general was reported less frequently than maternal mental illness; rates 
were in the range of $5 \%$ except for young Germans, who reported about $14 \%\left(X^{2}=\right.$ $21.6, p<.001)$. Maternal alcohol problems were reported more often in Germany than in Poland $\left(X^{2}=34.0, p<.001\right)$, with an age effect showing a higher percentage for the younger participants. Paternal alcohol problems were reported by about onequarter of the respondents, without any difference between countries and age groups $\left(X^{2}=2.93, p<.402\right)$.

\subsection{Abuse}

(Please insert Table 3 about here)

Regular physical punishment was reported more often by the younger groups, and more often in Germany than in Poland $\left(X^{2}=24.4, p<.001\right)$. Physical abuse was reported by about $15 \%$ of the respondents $\left(X^{2}=1.80, p=.615\right)$ and threat of physical abuse by about $17 \%\left(X^{2}=1.77, p=.622\right)$, without differences between countries or age groups. Physical arguments between the parents were reported by about one-fourth of the subjects; also, no differences between the countries and age groups were observed $\left(X^{2}=2.00, p=.573\right)$. However, when asked about the reasons for arguments between the parents, differences could be observed: the younger respondents in both countries reported arguments due to the temperaments of their parents more often $\left(X^{2}=34.6, p<.001\right)$ than did the older respondents. Germans reported more parental arguments due to financial problems and jealousy than did Poles $\left(X^{2}=14.5, p=.002 ; X^{2}=12.2, p=.007\right)$. An interacting age effect indicated jealousy as a more frequent reason for arguments between parents of older respondents in Germany, whereas in Poland parental arguments due to jealousy were reported more often by younger respondents. No differences were found regarding arguments between parents because of alcohol; the rate was constantly high, at about $25 \%$.

Unwanted sexual experiences were reported more often in Germany than in Poland $\left(X^{2}=12.7, p=.005\right)$, as were experiences that were considered to be sexual abuse $\left(X^{2}=16.1, p<.001\right)$, i.e. in Poland about $5 \%$ and in Germany about $13 \%$ reported sexual abuse. 
3. 4. Alcohol consumption and suicidality

(Please insert Table 4 about here)

About $20 \%$ of the subjects in the older groups reported that they never drink alcohol, compared with about $12 \%$ of the younger subjects $\left(X^{2}=17.9, p<.001\right)$; higher rates of never drinking were observed in Germany than in Poland. All four symptoms that were taken from the CAGE questionnaire were more often assented to by Poles than by Germans. In Poland no age effect was seen, whereas in Germany the rates of CAGE symptoms were higher for the younger respondents. Reported suicidality was generally higher in Germany than in Poland $\left(X^{2}=70, p<\right.$ .001). This result holds true for all three categories: suicide attempts, suicide plans, and ideations. The data show that Poles of the older group, in particular, reported low suicidality.

The only significant predictor for suicide attempts in both country was childhood physical abuse $(p<.001$, table 5$)$. The risk of reporting a suicide attempt was strongly increased in those participants who reported abuse (pseudo $\mathrm{R}^{2}=10,9 \%$ ). It should be noted however, that other effects were close to significance, i.e. the interaction between childhood sexual abuse and country had a $p$ value of $p=.022$. Possible alcohol abuse was predicted by two variables: Gender and Country. Men drink more than women, Poles more than Germans. Both effects did not explain much variance, i.e. $2.3 \%$. Possible alcohol problems and reported suicide attempts were positively associated $\left(X^{2}=27.27\right.$, p y .001$), 20.4 \%$ of the subjects with possible alcohol abuse reported at least one suicide attempt compared to $6.9 \%$ of the others.

\section{DISCUSSION}

In summary, childhood in Poland was described consistently more in favourable terms than in Germany. This outcome might reflect true experiences, of course, but we believe an alternative explanation could be that there is some idealisation among Polish respondents. When we analysed the demographic data, some inconsistencies appeared that can be interpreted as suggesting possible 
idealisation. The Poles felt more secure at home during their childhoods than the Germans; yet, $80 \%$ of the former reported that one of their parents was absent from home for a long period of time, i.e. mother or father was not available. Poles also think that they are highly professional, but a comparison of the data between Poland and Germany shows an unrealistic or at least questionable tendency among Polish respondents when reporting their profession. In no country does more than one-half of the population belong to the Registrar General's Classification categories I and II ( high- and low-grade professional Goldthorpe and Hope 1974). Regarding this variable, the Germans seem to be more realistic: only $20 \%-30 \%$ of them reported that they belonged in these two categories of profession. In addition, Poles think of themselves as successful pupils at school much more than Germans do; admittedly, this finding also could reflect differences in the school systems.

Finally, the hypothesis of idealisation may be supported by the answer to the question of whether one thinks that she or he was a wanted child. Eighty percent of Poles believe they were wanted children, compared with only $50 \%$ of Germans. This perception seems unrealistic high even when one considers that from 1956 to 1993 abortion was allowed in Poland during the first 12 weeks of pregnancy and was widely practiced.

The most striking findings among the German probands were the very high rates of mental problems or nervous disorders, particularly among their mothers, as well as high rates of suicide attempts, plans, and ideations reported for the probands themselves. The results show that Germans reported twice the rates of mental disorders in their parents than did Poles-with the exception of fathers in the older groups. The latter result could reflect the fact that these fathers were absent, most probably due to war (Radebolt 2000). The former result may illustrate a state of poor mental health in Germany but also may be partly an effect of greater social acceptance of mental disorders in Germany than in Poland. Also striking in this survey was the high rate of childhood sexual abuse in Germany-it greatly exceeds the rates shown by previous surveys (Wetzels 1997; Andrews et al. 2002). No explanation for this effect could be found; in this regard, the Polish data are more plausible. Harsh regular punishment was reported in Germany more than twice as often as in Poland, an outcome that confirms the cliché that the Germans traditionally beat their children. Concerning alcohol, a strange pattern was seen in 
Germany: fathers were reported to have had as many alcohol problems as fathers in Poland and German mothers even more than Polish mothers, but the probands themselves did not feel bad or guilty about their drinking. It is not plausible that in a country where the parents drink, children do not drink. A representative survey using standardized methodology (CIDI: World Health Organization 1990) in Germany revealed a rate of $3.8 \%$ of alcoholic depend subjects (Meyer et al. 2000) - comparable data for Poland were not found. A look at the objective data reveals that alcohol consumption in Germany was consistently about 10 litres per person and year (Statistisches Bundesamt 2009a), whereas in Poland it increased from about six litres in the years after the war to eight to nine at the millennium (Landberg 2008). Perhaps we can observe here an opposite tendency to the one concerning the idealisation pattern observed among the Polish group. The Germans might be trivialising their alcohol problems and underestimating the consequences of their alcohol consumption. This interpretation is supported by the results of a study by Stock et al. (2009), who asked students in six different countries if alcohol selling should be forbidden on the campus. In this study, $70 \%$ of the Polish students consented, compared to only $20 \%$ of the German students. Childhood physical abuse proved to be a strong risk factor for suicide attempts in both countries, a result found in Poland and Germany on a different samples before (Dragan and LisTurlejska 2007; Hardt et al. 2008). Surprisingly, possible alcohol abuse was predicted by sex and country only, no childhood adversity found entrance into the risk factor model. It is possible, that the CAGE-questions, even if widely used in psychiatry, partly measure a self critical reflection on one's own alcohol consume rather than abuse (Chan et al. 1994).

Our results also reveal some interesting time trends in both countries. One trend concerns parental chronic illness and parental pain: the younger groups in both countries reported considerably fewer problems in the functioning of their parents than the older groups. We think this finding could reflect the effects of better economic and medical conditions and a longer break from the disturbing consequences of World War II. Another time trend is worrisome: regular (i.e. habitual) harsh, physical punishment was reported more often by the younger cohorts than by the older ones. Of course, this result does not necessarily mean that physical abuse is increasing over time; indeed, some data from the US and the 
UK show an opposite trend (Gilbert et al. 2009). It is possible that the younger generation may respond to this item more sensitively; however, the positive time trend regarding sexual and physical abuse as observed in other countries cannot be postulated in Poland and Germany.

Summarising our results, we can say that the comparison of retrospective data on childhood and childhood adversities in Poland and Germany-two countries with different social and economic systems-reveals two different ways of coping. The Poles have a good opinion of their parents and may partly regulate their emotions by drinking alcohol (Taylor et al. 1997; Schier 2005). They practise idealisation, a mechanism that allows them to avoid mentalising, i.e. thinking about the existential, difficult problems of everyday life and asking questions about the past and about the intentions and emotions of their caregivers (Allen and Fonagy 2009). The Germans seem to be generally more open in their evaluation of the past but may tend to magnify other people's problems by trivialising their own.

Supplementing the focus of the discussion on the negative aspects of family image, our results also present some positive features of perceptions of childhood by residents of Poland and Germany. The mean values for the feeling of being secure at home ranged between $70 \%$ and $80 \%$ in both countries; this outcome indicates that most subjects at least felt subjectively secure within their families. We believe that this result can be explained partly by the presence of the grandparents in the children's upbringing; such presence was reported by more than one-half of the respondents from both countries. The role of an alternative caregiver in the physical and psychological development of a person is strongly emphasized in attachment theory (Bowlby 1951; Bowlby 1958; Bowlby 1969; Bowlby 1973; Bowlby 2004; Schier 2009).

The study has various limitations. (1) The present data were collected via Internet and are not representative of the populations of both countries. Participants were younger and better educated than average in both Poland and Germany. It is not fully known how Internet users differ from the general population. Therefore, this method of data collection may have caused a bias in the results. (2) Even though the items were translated and back-translated and discrepancies discussed, it is still possible that the content was not identical. (3) In addition, there is always some concern that retrospective reports about childhood may be biased in some way. 
Hardt and Rutter (2004) showed that in most cases this type of bias may be smaller than researchers fear; nevertheless, it cannot be ruled out totally.

Given the limitations discussed above, the present study demonstrates interesting differences and analogies between Germany and Poland; such comparisons illustrate the extent to which the image of oneself and of one's family can be linked to specific social, economic, and cultural factors. Our results might be directly useful for the purposes of educational policy-making when one considers the latest trends, which stress the importance of stimulating the development of mentalization. Mentalization refers to the capacity to think and talk about the past, present, and future of a person and to reflect on his or her social experiences and emotions (Allen and Fonagy 2009). These skills play an important role in the prevention of mental illness and in the development of a positive, realistic image of the self and other people (Schier 2009). 
Childhood Adversities in Poland and Germany

\section{Acknowledgements}

The present work was supported, in part, by the Heigl-Stiftung, Düsseldorf, and the Köhler-Stiftung, Essen. 


\section{Conflicts of Interest}

- None declared. 


\section{References:}

Allen JA, Fonagy P (2009) Mentalisierungsgestützte Therapie. Das MBT-Handbuch - Konzepte und Praxis. Klett-Cotta, Stuttgart

Andrews G, Corry J, Issakidis C, Slade T, Swanston H (2002) Comparative risk assessment: child sexual abuse. Final report WHO Collaborating Centre on Evidence and Health Policy in Mental Health. St. Vincent's Hospital, Sydney, pp Australia

Bolte G, Tamburlini G, Kohlhuber M Environmental inequalities among children in Europe--evaluation of scientific evidence and policy implications. Eur J Public Health 20:14-20

Bowlby J (1951) Mental care and mental health. WHO, Geneva

Bowlby J (1958) The nature of childs tie to his mother. International Journal of Psycho-Analysis 39:350-373

Bowlby J (1969) Attachment and loss. Vol 1: Attachment. Basic Books, New York

Bowlby J (1973) Attachment and loss. Vol 2: Separation: anxiety and anger. Basic Books, New York

Bowlby R (2004) Fifty Years of Attachment Theory. Karnac, London

Chan AW, Pristach EA, Welte JW (1994) Detection by the CAGE of alcoholism or heavy drinking in primary care outpatients and the general population. J Subst Abuse 6:123-135

Cohen J (1988) Statistical power analysis for behavioural sciences. Lawrence Erlbaum Associates, Hillsdale, NY

DiLillo D, Peugh J, Walsh K, Panuzio J, Trask E, Evans S (2009) Child maltreatment history among newlywed couples: a longitudinal study of marital outcomes and mediating pathways. J Consult Clin Psychol 77:680-692

Dong M, Anda RF, Felitti VJ, Dube SR, Williamson DF, Thompson TJ, Loo CM, Giles WH (2004) The interrelatedness of multiple forms of childhood abuse, neglect, and household dysfunction. Child Abuse Negl 28:771-784

Dragan M, Lis-Turlejska M (2007) Lifetime exposure to potentially traumatic events in a sample of alcoholdependent patients in Poland. J Trauma Stress 20:1041-1051

Drieskens S, Van Oyen H, Demarest S, Van der Heyden J, Gisle L, Tafforeau J (2009) Multiple risk behaviour: increasing socio-economic gap over time? Eur J Public Health

Euser EM, van Ijzendoorn MH, Prinzie P, Bakermans-Kranenburg MJ (2010) Prevalence of child maltreatment in The Netherlands. Child Maltreat 15:5-17

Ewing JA (1984) Detecting alcoholism. The CAGE questionnaire. JAMA 252:1905-1907

Felitti VJ, Anda RF (2009) The Relationship of Adverse Childhood Experiences to Adult Medical Disease, Psychiatric Disorders, and Sexual Behavior: Implications for Healthcare. In: Lanius R, Vermetten E (eds) The Hidden Epidemic: The Impact of Early Life Trauma on Health and Disease. Cambridge University Press, Cambridge

Finkelhor D, Turner H, Ormrod R, Hamby SL (2009) Violence, abuse, and crime exposure in a national sample of children and youth. Pediatrics 124:1411-1423

Gilbert R, Widom CS, Browne K, Fergusson D, Webb E, Janson S (2009) Burden and consequences of child maltreatment in high-income countries. Lancet 373:68-81

Goldthorpe JH, Hope K (1974) The Social Grading of Occupations. Oxford, Clarendon

GUS (2009) Glówny Urzad Statystyczny. Vol. received on 17.11.2009, www.stat.gov.pl

Hardt J (2004) Psychische Langzeitfolgen manifester Kindheitsbelastungen: Die Rolle von Eltern-KindBeziehungen. Pabst, Lengerich

Hardt J, Egle UT, Engfer A (2003) Der Kindheitsfragebogen, ein Instrument zur Beschreibung der erlebten Kindheitsbeziehungen zu den Eltern. Z Diff Diag Psychol 24:33-43

Hardt J, Egle UT, Johnson JG (2007) Suicide attempts and retrospective reports about parent-child relationships: evidence for the affectionless control hypothesis. GMS - Psychosoc Med 2007-4:DOC12

Hardt J, Rutter M (2004) Validity of adult retrospective reports of adverse childhood experiences: review of the evidence. J Child Psychol Psychiatry 45:260-273

Hardt J, Sidor A, Nickel R, Kappis B, Petrak F, Egle UT (2008) Childhood adversities and suicide attempts: a retrospective study. J Fam Violence 23:713-718

Havas J, Bosma H, Spreeuwenberg C, Feron FJ (2009) Mental health problems of Dutch adolescents: the association with adolescents' and their parents' educational level. Eur J Public Health

Landberg J (2008) Alcohol and suicide in eastern Europe. Drug Alcohol Rev 27:361-373

Meyer C, Rumpf HJ, Hapke U, Dilling H, John U (2000) Lebenszeitprävalenzen psychischer Störungen in der erwachsenen Allgemeinbevölkerung. Ergebnisse der TACOS-Studie. Nervenarzt 71:535-542.

Radebolt H (2000) Abwesende Väter. Vandenhook \& Rupprecht, Göttingen 
Schier K (2005) Bez tchu i bez slowa. Wiez psychiczna i regulacja emocji u osób chorych na astme oskrzelowa. Gdanskie Wydawnictwo Psychologiczne., Gdansk

Schier K (2009) Piekne brzydactwo. Problematyka obrazu ciala I jego zaburzen. Wydawnictwo Naukowe Scholar, Warszawa

SPSS inc. (2009) V17.0. Chicago, Illinois

StataCorp (2004) Stata Statistical Software release 9.2, College Station, Texas

Statistisches Bundesamt (2009a) Datenreport 2006.

Statistisches Bundesamt (2009b) Einkommen und

Verdienste.http://www.destatis.de/jetspeed/portal/cms/Sites/destatis/Internet/DE/Content/Statistiken/V erdiensteArbeitskosten/Bruttoverdienste/Tabellen/Content50/LangeReiheD,templateId=renderPrint.ps $\underline{\mathrm{ml}}$

Stock C, Mikolajczyk R, Bloomfield K, Maxwell AE, Ozcebe H, Petkeviciene J, Naydenova V, MarinFernandez B, El-Ansari W, Kramer A (2009) Alcohol consumption and attitudes towards banning alcohol sales on campus among European university students. Public Health 123:122-129

Taylor GJ, Bagby RM, Parker JDA (1997) Disorders of Affedt Regulation. Alexithymia in Medical and Psychiatric Illness. Cambridge University Press, Cambridge

Wetzels P (1997) Gewalterfahrungen in der Kindheit: Sexueller Missbrauch, körperliche Misshandlung und deren langfristige Konsequenzen. Nomos, Baden-Baden

World Health Organization (1990) Composite International Diagnostic Interview, Geneva

Zagozdzon P, Zaborski L, Ejsmont J (2009) Survival and cause-specific mortality among unemployed individuals in Poland during economic transition. J Public Health (Oxf) 31:138-146 
Table 1: Demographics

\begin{tabular}{|c|c|c|c|c|c|c|}
\hline \multirow[b]{2}{*}{ Variable } & \multicolumn{2}{|c|}{ Poland } & \multicolumn{2}{|c|}{ Germany } & \multirow[b]{2}{*}{$x^{2} / t$} & \multirow[b]{2}{*}{$\mathrm{p}$} \\
\hline & $\leq 40$ & $>40$ & $\leq 40$ & $>40$ & & \\
\hline Sex (\% female) & 58.7 & 53.2 & 54.8 & 56.0 & 1.69 & 0.640 \\
\hline Age: $\bar{x}(\mathrm{sd})$ & \multicolumn{2}{|c|}{$38.7(14.4)$} & \multicolumn{2}{|c|}{$39.3(16.1)$} & & 0.416 \\
\hline \multicolumn{7}{|l|}{ Current partner in life (\%) } \\
\hline Married & 35.8 & 65.9 & 38.0 & 62.8 & & \\
\hline Stable relationship $>6$ months & 34.7 & 9.5 & 43.2 & 62.8 & & \\
\hline Stable relationship $\leq 6$ months & 5.2 & 1.4 & 3.6 & 20.4 & & \\
\hline No stable relationship & 18.8 & 15.5 & 14.8 & 0.0 & & \\
\hline Other & 5.6 & 7.7 & 0.4 & 5.2 & 131.25 & 0.001 \\
\hline \multicolumn{7}{|l|}{ What is your profession? (\%) } \\
\hline $\begin{array}{l}\text { I) Higher-grade professional, administrator or } \\
\text { manager }\end{array}$ & 10.3 & 22.0 & 6.5 & 9.4 & & \\
\hline $\begin{array}{l}\text { II) Lower-grade professional, administrator or } \\
\text { manager; higher-grade technician }\end{array}$ & 42.5 & 43.5 & 16.0 & 22.2 & & \\
\hline IIla) Skilled non-manual employee & 21.5 & 16.8 & 48.9 & 33.8 & & \\
\hline IIlb) Skilled manual employee & 9.2 & 10.7 & 0.9 & 6.4 & & \\
\hline IV) Partly skilled worker & 4.6 & 5.6 & 21.6 & 21.4 & & \\
\hline V) Unskilled labourer & 11.9 & 11.9 & 6.1 & 6.8 & 203.72 & 0.001 \\
\hline \multicolumn{7}{|l|}{ Religious Denomination } \\
\hline Christian & 86.5 & 87.3 & 51.4 & 44.1 & & \\
\hline Other & 5.1 & 1.9 & 4.7 & 0.5 & & \\
\hline None & 8.5 & 10.9 & 43.9 & 55.4 & 314.2 & 0.001 \\
\hline
\end{tabular}


Table 2: History within and outside the family and family problems

\begin{tabular}{|c|c|c|c|c|c|c|}
\hline \multirow[b]{2}{*}{ Variable } & \multicolumn{2}{|c|}{ Poland } & \multicolumn{2}{|c|}{ Germany } & \multirow[b]{2}{*}{$X^{2}, F$} & \multirow[b]{2}{*}{$\mathrm{p}$} \\
\hline & $\leq 40$ & $>40$ & $\leq 40$ & $>40$ & & \\
\hline \multicolumn{7}{|l|}{ Do you believe you were a planned child? } \\
\hline Very likely & 84.4 & 78.6 & 53.6 & 48.0 & & \\
\hline Probably not & 7.3 & 9.5 & 21.2 & 32.0 & & \\
\hline I don't know & 8.3 & 11.8 & 25.2 & 20.0 & 123.78 & 0.001 \\
\hline Did you feel secure/cared-for at home? & 82.41 & 78.49 & 73.83 & 71.52 & 51.00 & 0.001 \\
\hline $\begin{array}{l}\text { Was one of your parents absent for a period } \\
\text { of more than } 6 \text { months at a time? }\end{array}$ & 81.6 & 76.8 & 23.2 & 23.6 & 319.04 & 0.001 \\
\hline $\begin{array}{l}\text { Were your grandparents essential caregivers } \\
\text { who looked after you? }\end{array}$ & 63.2 & 53.2 & 60.4 & 54.0 & 7.52 & 0.057 \\
\hline Was school easy for you? Were you a & 37.2 & 41.4 & 16.8 & 31.2 & 63.60 & 0.001 \\
\hline \multicolumn{7}{|l|}{ successful pupil at school? } \\
\hline Mother chronically ill or handicapped? & 6.9 & 11.8 & 5.2 & 12.4 & 11.63 & 0.009 \\
\hline Father chronically ill or handicapped? & 6.9 & 9.5 & 8.4 & 12.4 & 5.03 & 0.170 \\
\hline Did your mother suffer from chronic pain? & 9.4 & 18.2 & 4.8 & 10.4 & 23.00 & 0.001 \\
\hline Did your father suffer from chronic pain? & 5.6 & 9.1 & 8.8 & 14.0 & 11.50 & 0.009 \\
\hline Did your mother suffer from mental problems & 10.8 & 3.6 & 20.0 & 26.8 & 56.88 & 0.001 \\
\hline \multicolumn{7}{|l|}{ or nervous disorders? } \\
\hline Did your father suffer from mental problems & 5.2 & 5.9 & 13.6 & 4.9 & 21.57 & 0.001 \\
\hline \multicolumn{7}{|l|}{ or nervous disorders? } \\
\hline Did your mother have an alcohol problem? & 8.0 & 2.3 & 17.2 & 14.8 & 33.98 & 0.001 \\
\hline Did your father have an alcohol problem? & 27.4 & 27.3 & 25.6 & 21.6 & 2.93 & 0.402 \\
\hline
\end{tabular}


Table 3: Abuse

\begin{tabular}{|c|c|c|c|c|c|c|}
\hline \multirow[b]{2}{*}{ Variable } & \multicolumn{2}{|c|}{ Poland } & \multicolumn{2}{|c|}{ Germany } & \multirow[b]{2}{*}{$X^{2}$} & \multirow[b]{2}{*}{$p$} \\
\hline & $\leq 40$ & $>40$ & $\leq 40$ & $>40$ & & \\
\hline $\begin{array}{l}\text { Did an adult in the household hit you hard } \\
\text { enough to bruise/injure you? }\end{array}$ & 15.3 & 15.9 & 14.8 & 18.8 & 1.80 & 0.615 \\
\hline Were you harshly punished on a regular basis? & 5.9 & 2.7 & 14.4 & 8.0 & 24.36 & 0.001 \\
\hline $\begin{array}{l}\text { Did an adult in the household act in a way that } \\
\text { made you afraid that you would be physically } \\
\text { hurt? }\end{array}$ & 19.6 & 17.2 & 15.3 & 17.7 & 1.77 & 0.622 \\
\hline $\begin{array}{l}\text { Did your parents regularly have physical } \\
\text { arguments? }\end{array}$ & 28.8 & 25.6 & 25.3 & 23.2 & 2.00 & 0.573 \\
\hline $\begin{array}{l}\text { Were there experiences of a sexual nature with } \\
\text { persons significantly older than you that were } \\
\text { distressing for you? }\end{array}$ & 6.9 & 9.5 & 14.8 & 15.2 & 12.73 & 0.005 \\
\hline If so, would you call this sexual abuse? & 4.4 & 4.8 & 12.2 & 13.6 & 16.06 & 0.001 \\
\hline \multicolumn{7}{|l|}{ Were there regular (habitual) arguments between } \\
\hline your parents? If so, & & & & & & \\
\hline because of their temperaments & 36.5 & 15.9 & 32.4 & 21.2 & 34.60 & 0.001 \\
\hline because of finances & 28.1 & 27.3 & 36.4 & 40.8 & 14.51 & 0.002 \\
\hline because of alcohol & 26.7 & 26.8 & 23.2 & 26.4 & 1.18 & 0.758 \\
\hline because of jealousy & 11.8 & 6.8 & 15.2 & 22.8 & 12.15 & 0.007 \\
\hline
\end{tabular}


Table 4: Alcohol Possible alcohol consumption abuse and suicidality

\begin{tabular}{|c|c|c|c|c|c|c|}
\hline \multirow[b]{2}{*}{ Variable } & \multicolumn{2}{|c|}{ Poland } & \multicolumn{2}{|c|}{ Germany } & \multirow[b]{2}{*}{$X^{2}$} & \multirow[b]{2}{*}{$\mathrm{p}$} \\
\hline & $\leq 40$ & $>40$ & $\leq 40$ & $>40$ & & \\
\hline Never consume alcohol (\%) & 10.1 & 18.2 & 14.8 & 23.2 & 17.93 & 0.001 \\
\hline $\begin{array}{l}\text { Have you ever felt you should cut down on } \\
\text { your drinking? }\end{array}$ & 17.8 & 29.4 & 17.8 & 6.3 & 34.40 & 0.001 \\
\hline $\begin{array}{l}\text { Have people annoyed you by criticizing } \\
\text { your drinking? }\end{array}$ & 10.4 & 13.6 & 6.8 & 0.8 & 30.41 & 0.001 \\
\hline $\begin{array}{l}\text { Have you ever felt bad or guilty about your } \\
\text { drinking? }\end{array}$ & 49.0 & 40.0 & 18.4 & 11.6 & 115.73 & 0.001 \\
\hline $\begin{array}{l}\text { Have you ever had a drink in the morning to } \\
\text { get rid of a hangover? }\end{array}$ & 6.9 & 10.5 & 6.0 & 0.0 & 25.01 & 0.001 \\
\hline Suicidal ideation (\%) & & & & & & \\
\hline Yes, at least one attempt & 7.3 & 6.4 & 11.2 & 10.0 & & \\
\hline Yes, at least one plan & 4.9 & 4.1 & 5.2 & 6.0 & & \\
\hline Yes, serious thoughts about suicide & 18.4 & 13.6 & 35.2 & 19.2 & & \\
\hline Never seriously considered suicide & 63.4 & 71.8 & 48.4 & 55.6 & & \\
\hline DI don't know & 5.9 & 4.1 & 0.0 & 9.2 & 69.83 & 0.001 \\
\hline
\end{tabular}


Table 5: Regression tables for suicide attempts and alcohol abuse

Model: Suicide Attempt <- Physical Abuse

\begin{tabular}{|c|c|c|c|c|}
\hline Explanatory variable & $\begin{array}{l}\text { Estim. } \\
\text { coeff. }\end{array}$ & $\begin{array}{l}\text { Stand. } \\
\text { error }\end{array}$ & z-value & $\mathrm{p}$-value \\
\hline (Constant) & -2.93 & .15 & -18.69 & $<.001$ \\
\hline Physical abuse & 1.96 & .23 & 8.35 & $<.001$ \\
\hline
\end{tabular}

Terms not in the equation (values if added next)

\begin{tabular}{|c|c|c|c|c|}
\hline Explanatory variable & $\begin{array}{l}\text { Estim. } \\
\text { coeff. }\end{array}$ & $\begin{array}{c}\text { Stand. } \\
\text { error }\end{array}$ & $z$-value & $p$ - value \\
\hline Country x Phys. Abuse & .68 & .48 & 1.42 & .157 \\
\hline Sexual Abuse & .56 & .25 & 1.92 & .054 \\
\hline Country x Sex. Abuse & -1.35 & .59 & -2.28 & .022 \\
\hline Age & -.06 & .23 & -.26 & .796 \\
\hline Sex & -.47 & .26 & -1.84 & .066 \\
\hline Country & .48 & .24 & 2.01 & .045 \\
\hline
\end{tabular}


Table 5 (continued)

\begin{tabular}{|c|c|c|c|c|}
\hline Explanatory variable & $\begin{array}{l}\text { Estim. } \\
\text { coeff. }\end{array}$ & $\begin{array}{c}\text { Stand. } \\
\text { error }\end{array}$ & z-value & $p$-value \\
\hline (Constant) & -2.43 & .18 & -13.65 & $<.001$ \\
\hline Sex & .53 & .19 & 2.84 & .005 \\
\hline Country & .59 & .19 & 3.09 & .002 \\
\hline
\end{tabular}

Terms not in the equation (values if added next)

Explanatory variable

Estim. Stand.

$z$-value $p$-value coeff. error

\begin{tabular}{lrrrr}
\hline Physical Abuse & .07 & .26 & .25 & .801 \\
Country x Phys. Abuse & -.87 & .53 & -1.63 & .104 \\
Sexual Abuse & .34 & .29 & 1.15 & .249 \\
Country x Sex. Abuse & 2.28 & 1.07 & 2.12 & .034 \\
Age & -.34 & .19 & -.1 .76 & .078 \\
\hline
\end{tabular}

Note: Values for interaction terms are displayed when both underlying main effects were included into the model. 